\title{
International Order in Diversity: War Trade and Rule in the Indian Ocean
}

\section{Andrew Phillips og J. C. Sharman \\ Cambridge, Cambridge University Press, 2015}

Anmeldt av Stian A. E. Eisenträger ${ }^{\star}$, $M S c$, utenriksjournalist, Verdens Gang

Den historiske utbredelsen av heterogene internasjonale systemer synes å kunne være et forvirrende element for mange som forsker på internasjonale relasjoner (IR). Tradisjonelt har forskere innenfor IR fokusert på problemet med å skape orden blant like enheter - altså suverene stater - som opptrer i et anarki, og gitt mindre oppmerksomhet til hierarkiske internasjonale systemer. Desto mindre forskning er gjort på heterogene systemer, som hverken styres av anarkistisk eller hierarkisk logikk. Antakelsen om at internasjonal politikk dreier seg om relasjonene mellom like enheter - suverene stater - har ført til at man i liten grad har forsøkt å forklare samspillet mellom ulike enheter. Etablerte IR-teorier anser nemlig homogenitet - altså et system bestående av like enheter - som det normale, og heterogenitet - et system med et mangfold av ulike enheter - som unntaket, i internasjonale systemer. Forfatterne kommer med kritikk mot klassisk realisme, liberalisme, den engelske skolen og konstruktivisme for å ha et bias for monokultur fremfor blandede internasjonale systemer. De fremholder at alle disse teoretiske tradisjonene implisitt tilbakeviser idéen om orden i mangfold, og at de anser blandede internasjonale systemer enten som stoppested på veien mot en mer ordnet og homogen fremtid, eller som symptom på oppløsningen og nedgangen for internasjonal orden.

Boken føyer seg inn $\mathrm{i}$ forskningen som viser at heterogenitet historisk sett har vært normen, fremfor å være unntaket. Også når det gjelder den berømte freden i Westfalen i 1648, som er blitt fremstilt som selve milepælen eller vendepunktet på vei fra middelalderens mangfoldige internasjonale system til det moderne anarkiet av suverene stater (Gross 1948), viser nyfortolkende forskning den vedvarende uensartetheten til de politiske enhetene i Vest-Europa også etter Westfalenfreden (se for eksempel: De Carvalho et al. 2011; Krasner 1993; Nexon 2009; Osiander 2007).

^Korrespondanse: Stian A. E. Eisenträger. Email: stian.eisentrager@gmail.com 
Hovedpoenget $\mathrm{i}$ boken er imidlertid at det $\mathrm{i}$ dagens etablerte IR-teorier er en utbredt oppfatning av at politiske enheter vil bli stadig mer like, desto mer de interagerer. Forfatterne mener at dette ikke henger på greip, og viser til at det i brorparten av moderne tid har eksistert et vell av forskjellige politiske enheter, som på forskjellig vis har spilt sammen - uten å bli mer like hverandre. Det varige mangfoldet av politiske enheter demonstrerer forfatterne gjennom sin analyse av områdene rundt Det indiske hav fra år 1500 til 1750 - den «orientalske globaliseringens» vugge. Som eksempler bruker forfatterne blant annet portugisiske korsfarere, sendt av kongen på jakt etter kryddere og kristne allierte i Østen; det enorme Mughalriket, med sitt sentralasiatiske kavaleri, hvis ledere hevdet å være direkte etterkommere av Djengis Khan; de hollandske og engelske handelskompaniene, forløperne til dagens multinasjonale selskaper, som gjorde Vestens kolonisering av Asia mulig. Alle disse politiske enhetene var forskjellige både hva gjaldt kultur, institusjonell form, og politiske og økonomiske mål.

Skulle man holdt seg til forklaringen til etablerte IR-teorier om at økt interaksjon fører til større ensartethet over tid, burde man ha sett at den århundrelange prosessen med global integrering, som startet med den første globaliseringsbølgen på 1500-tallet, samstemmer med utviklingen av en felles form for politiske enheter, fremholder forfatterne. I motsetning til hva mye av den klassiske IR-teorien skisserer, eksisterte altså disse svært forskjellige politiske enhetene side om side og dannet et svært uensartet, internasjonalt system som vedvarte gjennom flere århundrer. Phillips og Sharman viser hvordan diversiteten i Indiahavsregionen først oppsto, og forklarer hvorfor samspillet imellom enhetene ikke førte til konvergens mot en felles politisk form. Vi får også forklart hvordan de svært ulike aktørene stabiliserte sine forhold til hverandre uten å dele normer og en felles kulturell forståelse. Forfatterne tar utgangspunkt $\mathrm{i}$ at forskjellige politiske enheter (suverene stater, imperier og handelskompanier) har forskjellige målsettinger, og går forskjellige veier for å oppnå dem. Ved å ha forskjellige mål og midler, mener forfatterne at man unngår nullsumspill-logikken som preger forholdene mellom like enheter. De mener diversitet i systemet oppnås når enhetene er forskjellige nok, og at varighet i systemet oppnås ved at de politiske enhetene har sammenfallende oppfatninger om organiseringen av politisk autoritet. På denne måten kunne så forskjellige enheter som for eksempel Mughalimperiet og de europeiske handelskompaniene akseptere delte og overlappende krav på autoritet over det samme territoriet. Til slutt viser forfatterne også hvordan dette mangfoldet fortsatte å sette sitt preg på Indiahavsregionen også etter den vestlige koloniseringen tok til for fullt på slutten av 1700-tallet.

Mye av grunnfjellet for de etablerte teoriene i IR bygger på historiske erfaringer hovedsakelig fra Vest-Europa i moderne tid. En slik behandling av Indiahavsregionen som internasjonalt system som Phillips og Sharman har utført med denne boken er derfor ikke bare forfriskende, men også et viktig korrektiv og en øyeåpner for teoretikere som av ulike grunner har ignorert de historiske erfaringene i de andre av verdens regioner. Boken gir ikke bare et teoretisk bidrag, men er også fullspekket av historisk empiri, som viser samspillet mellom aktører i Europa, Midtøsten og Asia i tidlig moderne tid. Det går selvfølgelig ikke å rekke over alt på drøye 220 sider, og 
forfatterne understreker at de bare så vidt har skrapet i overflaten av regionens rike og fascinerende historie. Mest grundig behandlet blir Mughalriket, som strakte seg over store deler av Det indiske subkontinent, det portugisiske Estado da Índia, i tillegg til de hollandske og engelske handelskompaniene. De østafrikanske Swahilisamfunnene blir berørt, men får ikke en like omfattende behandling. Ei heller får vi lese noe særlig om andre kongedømmer i det østlige og sørlige Afrika, som også strengt tatt må sies å ha vært del av det internasjonale systemet i Indiahavsregionen.

Et annet punkt for kritikk, er at forfatterne tar utgangspunkt $i$ at nåtidens politiske enheter $\mathrm{i}$ internasjonale relasjoner er homogene, og at vi i dag har en monokultur av suverene stater. Enkelte vil nok kunne komme med noen innvendinger mot denne påstanden, tatt i betraktning både såkalt mislykkede stater, og aktører og institusjoner som utfordrer den moderne statens suverenitet, som for eksempel private sikkerhetsselskaper, organiserte kriminelle og ikke minst EU.

Boken kan uansett anbefales både for studenter og erfarne forskere innenfor internasjonale studier, og kan forhåpentligvis fungere som en døråpner til en del av studiet internasjonal politikk som strekker seg langt utenfor de velkjente områdene $\mathrm{i}$ Vest-Europa. Ikke minst kan det også være en inspirasjon til å dykke dypere ned i det som til nå har vært oversette regioner og historier. Her ligger et enormt potensiale for videre forskning på og utforskning av empiri, og ikke minst utvikling av teorier relatert til historiske internasjonale relasjoner.

\section{Referanser}

de Carvalho, B., H. Leira \& J. M. Hobson (2006) «The Big Bangs of IR: the myths that your teachers still tell you about 1648 and 1919», Millennium-fournal of International Studies, 39 (3): 735-58.

Gross, L. (1948) «The peace of Westphalia, 1648-1948», American fournal of International Law, 42 (1): $20-41$.

Krasner, S. D. (1993) «Westphalia and all that» i Judith Goldstein \& Robert O. Keohane (red.) Ideas and foreign policy: Beliefs, institutions, and political change. Ithaca: Cornell University Press (235-64).

Nexon, D. H. (2009) The struggle for power in early modern Europe: religious conflict, dynastic empires, and international change. Princeton: Princeton University Press.

Osiander, A. (2007) Before the State: Systemic Political Change in the West from the Greeks to the French Revolution. Oxford: Oxford University Press. 